УДК 330.101 .2

Тульчинська С. О.

доктор економ. наук, професор

Мілай А. О.

канд. економ. наук, доиент

Національний технічний університет України «КПI»

\title{
ПРОБЛЕМИ І НАСЛІДКИ ВЗАСМОДІЇ КРАЇН В ПРОЦЕСІ ВІДТВОРЕННЯ ВИРОБНИЦТВА
}

\section{ПРОБЛЕМЫ И ПОСЛЕДСТВИЯ ВЗАИМОДЕЙСТВИЯ СТРАН В ПРОЦЕССЕ ВОСПРОИЗВЕДЕНИЯ ПРОИЗВОДСТВА}

\author{
ISSUES AND IMPLICATIONS OF THE INTERACTION IN THE PLAY \\ PRODUCTION
}

Запропоновано методологічний підхід до аналізу причин і наслідків існування сучасної моделі економіки пропозищії і перевиробництва на основі дослідження економічної природи $i$ ролі фінансового сектора економіки в процесі відтворення виробництва та визначення основних чинників дефіциту торгівельного балансу розвинутих країн, безробіття, дефляиії $i$ економічної кризи.

У статті розглядаються форми взаємодії між розвинутими країнами і країнами, що розвиваються, виходячи з того, що вони належать до контурів відтворення з різним рівнем розвитку системи розподілу праиі. Доведено, що особливості відтворення виробництва $i$ спожсивання визначають систему економічних інтересів країн та певні наслідки торговоекономічної взаємодії. Встановлено, що наслідки торгівельної форми взаємодії для країн залежать від рівня розвитку системи розподілу прачі. Для країни з менш розвинутою системою розподілу праці та з більш високими витратами праці на одиницю продукції така форма взаємодії веде до утворення монокультурного типу виробництва. Країна, яка належить до розвинутої системи техніко-економічного відтворення і валюта якою постійно використовується в міжнародних розрахунках буде мати від’ємне торгівельне сальдо та зростаючий державний борг. Проаналізовано наслідки взаємодії двох контурів відтворення інвестиційного типу з різним рівнем розвитку системи розподілу праці. Доведено, щяо інвестиційна форма взаємодії країн з різним рівнем розвитку системи розподілу праиі призводить до порушення балансу виробнищтва і споживання, скороченню рівня доходів, $а$, отже, $i$ споживання в системі розвинутого контуру відтворення, появи безробіття $i$ економічної кризи.

Ключові слова: відтворення, розподіл праці, продуктивність праці, робоча сила, розвиток, торгівельний баланс, економічні відносини, товари, фінанси, інвестиції, розвинуті країни, країни, що розвиваються 
Предложен методологический подход к анализу причин и последствий существования современной модели экономики предложения и перепроизводства на основе исследования экономической природы и роли финансового сектора в прочессе воспроизведения производства и определения основных факторов дефицита торгового баланса развитых стран, безработицы, дефляции и экономического кризиса.

B статье рассматриваются формы взаимодействия между развитыли $и$ развивающимися странами, исходя из того, что они принадлежат к контурам воспроизведения с разным уровнем развития системы разделения труда. Доказано, что особенности воспроизведения производства и потребления определяют систему экономических интересов стран и последствия торгово-экономического взаимодействия. Установлено, что последствия торговой формы взаимодействия стран зависят от уровня развития системы разделения труда. Для страны с менее развитой системой разделения труда и с более высокими затратами труда на единииу продукиии такая форма взаимодействия ведет к образованию монокультурного типа производства. Страна, которая относится к развитой системе технико-экономического воспроизводства и валюта которой постоянно используется в международных расчетах, будет иметь отрицательное торговое сальдо и растущчий государственный долг. Проанализированы последствия взаимодействия двух контуров воспроизведения инвестиционного типа с разным уровнем развития системы разделения труда. Доказано, что инвестиционная форма взаимодействия стран с разнылм уровнем развития системы разделения труда приводит к нарушению баланса производства и потребления, сокращению уровня доходов, а, следовательно, и потреблению в системе развитого контура воспроизведения, появлению безработицы и экономического кризиса.

Ключевые слова: воспроизводство, разделение труда, производительность труда рабочей силы, развитие, торговый баланс, экономические отношения, товары, финансы, инвестиции, развитые страны, развивающиеся страны

A methodological approach is supposed for the analysis of the causes and consequences the existence modern economic model of supply and oversupply, which based on a study of the economic nature and the role of a financial sector in the process of production and reproduction of the main determining factors at trade deficit developed countries, unemployment, deflation and economic crisis.

The article considers the forms of cooperation between developed countries and developing countries, which based on the fact that they belong to the contours of reproduction with different levels of development of the division of labor. It is proved, that features reproduction of production and consumption determines the system of economic interests and the implications of trade and economic interaction. It was established that the effects of trade forms of cooperation for countries depend on the development of the division of labor. For countries with undeveloped system of division of labor and higher costs of labor per unit of output, this form of interaction leads to the formation of monoculture type of production. A country that belongs to the developed system feasibility and reproduction and currency which is heavily used in international payments will have a negative trade balance and increasing public debt. It has analyzed the effects of the investment type cooperation between the two circuits playback with different development levels of the division labor. It is proved that the investment form of interaction between countries with different development levels of the division labor leads to imbalance of production and consumption, reduction in income, 
and thus consumption system developed contour playback, the emergence of unemployment and economic crisis.

Keywords: reproduction, division of labor, productivity of labor, development, trade balance, economic relations, commodities, finance, investment, developed countries, developing countries

Вступ. В своїй відомій роботі «Початок політичної економії та оподаткування» Д. Рикардо досліджує питання торгівельних відносин між країнами з різним рівнем розвитку системи розподілу праці. На відміну від А.Сміта, він формулює свій варіант теорії порівняльних переваг і показує принципову можливість мати вигоду для обох країн незалежно від вартості їх робочої сили і продуктивності праці.

В подальшому дослідженні, не тільки економістів тих часів але й науковців сучасності, теорія порівняльних переваг не знайшла свого належного розвитку. В той же час, Д. Рікардо, визначивши основні методологічні напрямки дослідження взаємовідносин між країнами з різним рівнем розвитку економіки, не доводить своє дослідження до логічного завершення. Зупинившись на визначені умов при яких торгівля для обох країн стає вигідною, Д. Рікардо не продовжує аналіз. Він не визначає вплив тієї чи іншої форми взаємодії на торгівельний баланс країн, не визначає і тем більше не досліджує форми взаємодії i, що особливо важливо, не аналізує шляхи отримання прибутку і наслідки для обох країн його привласнення і подальшого використання. На нашу думку, дослідження і аналіз цих питань становить безумовний інтерес для економічної теорії, оскільки визначає основні чинники кризового стану сучасної економіки.

Дослідженню проблематики торгівельної та інвестиційної форми взаємодії країн, теорії кризи та проблем економічного зростання присвячено багато праць західних науковців, найбільш відомі з них, Дж. Гелбрейт [4], У. Ендгаль [21], Дж. Кейнс [6], К. Маркс [9], Л. Мізес [10], Д. Мілль [11], Д. Рікардо [13], Дж. Робинсон [14], Дж. Стігліц [15], Ф. Хаєк [18], Й. Шумпетер [20] тощо. А також вітчизняних вчених: М. Бойкова [1], М. Гнатишин [2], Т. Горянська [3], I. Іващук [5], Н. Кравчук [7], М. Кроленко [17], Ю. Макогон [8], А. Пельо [19], О. Тхор [17], С. Тхор [17], М. Швайка [19] та інші. Але, необхідно зазначити, що форми взаємодії між розвинутими країнами і країнами, що розвиваються, які належать до різних контурів відтворення з різним рівнем розвитку системи розподілу праці досліджено недостатньо.

Постановка завдання. Основною метою наукової статті $\epsilon$ визначення методологічного підходу до дослідження причин і наслідків існування сучасної моделі економіки пропозиції. 
Завдання роботи полягають у визначені основних чинників дефіциту торгівельного балансу розвинутих країн, появи безробіття, економічної кризи і дефляції. Окреме завдання дослідження полягає у визначені особливостей природи фінансового сектору економіки, його ролі у процесі відтворення виробництва і розвитку системи розподілу праці.

Методологія дослідження. Теоретичною та методологічною основою статті $є$ роботи вітчизняних і зарубіжних вчених в галузі дослідження природи взаємодії країн з різним рівнем розвитку системи розподілу праці. У роботі використовувались загальнонаукові та спеціальні методи дослідження економічних процесів i явищ. Із загальнонаукових методів застосовано: абстрактно-теоретичний, діалектичний, аналізу і синтезу та інші, які були використанні при узагальненні теоретико-методологічних положень

Результати дослідження. Аналізуючи форми взаємодії між розвинутими країнами і країнами що розвиваються, ми виходимо з того що вони, перш за все, належать до контурів відтворення з різним рівнем розвитку системи розподілу праці. I саме ці особливості відтворення виробництва і споживання визначають їх систему економічних інтересів, а також певні наслідки торгово-економічної взаємодії.

Визначимо чому, взагалі, така взаємодія стає можливою? Адже розвинута система розподілу праці дозволяє країні виробляти увесь асортимент надсучасної продукції, і тому теоретично вона може забезпечувати себе самостійно усім необхідним. В той же час, така економіка забезпечує не тільки високу продуктивність виробництва але й відповідну якість виробленої продукції.

Всі ці можливості принципово недосяжні для економіки яка базується на менш розвинутій системі розподілу праці. Апріорі така економіка виробляє тільки неконкурентоспроможну продукцію, до того ж обмеженого асортименту. В той же час, ці економіки технологічно несумісні і тому їх системи виробництва не можуть бути об'єднані в тій чи іншій формі. Як в таких умовах між ними може будуватися торгівельно-економічна модель взаємодії?

Визначимо принципові умови при яких виникає можливість торгівлі між двома економіками з різним рівнем розвитку. Розглянемо в якості прикладу дві країни які виробляють, наприклад, зерно і тканину, умовно назвімо їх літерами «А» і «Б». Будемо вважати, що в країні «А» обертається - долар, а в країні «Б», наприклад, бат. Загальні річні витрати праці на виготовлення продукції в країнах складають 1 млрд. л/год. В країні «А» виробляється 500 млн. центнерів зерна і 250 млн. погонних метрів тканини. Витрати праці на виготовлення 1 ц. зерна становлять 1л/год., на виготовлення 1 п./м. тканини 2 л/год. Відповідно, в країні 
«Б» виробляється 150 млн. центнерів зерна і 40 млн. погонних метрів тканини, а витрати праці на міру зерна відповідно - 4 л/год., на міру тканини 10 л/год. Вартість 1 години праці, наприклад, становить 1 дол. (\$1) в країні «А» i 1 бат (ㅁ1) в країні «Б».

В той же час, в країні «А» еквівалентним є обмін 1-го центнера зерна на 2 погонних метра тканини. В свою чергу, в країні «Б» еквівалентні пропорції обміну становлять - 1 центнер зерна на 2,5 погонних метра тканини. Якщо в одній з названих країн, або в третій країні знаходиться підприємець, якій помітив ці розбіжності в обміні, він може організувати торгівлю між країнами і отримати певний прибуток. Можливість для цього з'являється тоді коли співвідношення вартості 1 години праці між цими країнами становитиме не менш 4 разів, тобто співвідношення валют в даному випадку повинно становити $-\$ 1=\underline{\$} 4$.

У такому разі з'являється можливість продати 100 млн. центнерів зерна, що виробляється в країні «Б», в країну «А», отримавши таким чином, \$100 млн. В країні «А» купити на цю суму 40 млн. метрів тканини, витративши $\$ 80$ млн., i продати тканину в країні «Б». Прибуток від цієї торгівельної операції становитиме $\$ 20$ млн. В даному випадку джерелом отримання прибутку $\epsilon$ різниця у вартості робочої сили в різних по рівню розвитку системах технікоекономічного відтворення, тобто різних контурах відтворення.

В такій моделі у наступному циклі відтворення країна «А» буде задовольняти потреби зерна за рахунок власного виробництва на 400 млн. центнерів та за рахунок імпорту на 100 млн. центнерів. В той же час, вона збільшить виробництво тканини до 290 п./м. і буде експортувати 40 млн. метрів. Дефіцит торгівельного балансу країни становитиме \$20 млн. 3 виробництва вивільниться 20 тис. л/год., що відповідно збільшить кількість незайнятого населення.

Країна «Б» в наступному циклі відтворення буде виробляти 250 млн. центнерів зерна, а власне виробництво тканини відповідно згорнеться. Кількість зайнятого населення в ній не зміниться і дефіциту торгівельного балансу не буде.

Таким чином, можна зробити висновок, що наслідки торгівельної форми взаємодії для країн залежать від рівня розвитку системи розподілу праці. Для країни з менш розвинутою системою розподілу праці і, відповідно, з більш високими витратами праці на одиницю продукції така форма взаємодії веде до утворення монокультурного типу виробництва. Країна, яка належить до розвинутої системи техно-економічного відтворення і валюта якою постійно використовується в міжнародних розрахунках, буде мати від’ємне торгівельне 
сальдо i, як наслідок, зростаючий державний борг. Власно кажучи, саме таку картину ми спостерігаємо, наприклад, в США.

Більш того, для слаборозвинутої країни високотехнологічні види виробництва стають найбільш вразливими у разі розвитку торгівельних відносин 3 розвинутою економікою і скорочуються в першу чергу. За рахунок ренти конкурентними видами виробництва залишаються ті, що мають невисокий рівень переробки сировини або, взагалі, зайняті іiі видобутком.

Виникає питання, чому країна яка належить до контуру відтворення 3 високим рівнем розвитку системи розподілу праці i тому апріорі може забезпечити себе всім необхідним самостійно буде щось купувати в слаборозвинутому контурі відтворення. Відповідь досить проста. В країні «Б», яка в нашому прикладі саме таку систему відтворення представляє, немає іншого джерела отримання валюти в якій проводяться міжнародні розрахунки, в даному прикладі це валюта країни «А». Тому, якщо країна «А» хоче щось продати в іншу країну, вона спочатку повинна щось в цій країні купити. Ми не розглядаємо варіант надання міжнародного кредиту країні «Б», як додаткове джерело надходження валюти для проведення міжнародних торгівельних операцій. Хоча, безумовно, в сучасній системі міжнародних торгівельних відносин така практика присутня і дуже поширена.

Необхідно також пояснити чому, в свою чергу, у слаборозвинутої країни виникає потреба торгувати з розвинутою економічною системою. Відповідь на це питання лежить в площині оцінки функції корисності тих чи інших товарів для іiї населення.

Так, наприклад, є товари, які система відтворення слаборозвинутої країни не виробляє взагалі або виробляє невисокої якості. В той же час, їх корисність для певного прошарку споживачів цією країни дуже висока і вони готові за них платити високу ціну. Крім того, наявність достатньо значного рівня диференціації доходів в слаборозвинутій економічній системі створює можливість задовольнити попит на високотехнологічні імпортні товари з боку такої соціальної групи. I саме це породжує не тільки передумови але й можливості існування торгівлі між економіками різного рівня розвитку системи розподілу праці.

В цій моделі економічних відносин бізнес отримує прибуток діючи по формулі Г-Т-Г*, тобто по формулі фінансового сектора економіки. В таких випадках кошти фінансового сектора економіки можуть вкладатися не тільки в купівлю певного товару на ринку але і в створення відповідної ринкової інфраструктури, наприклад, логістичної системи, яка дозволяє забезпечити 
зберігання i своєчасну доставку товару. Умова, яка повинна при цьому зберігатися - це можливість отримання прибутку на відміну від реального сектора економіки, де суб'єкти діють по формулі Т(а)-Г-Т(б) і отримують не прибуток а можливість забезпечити через обмін свої потреби в тих чи інших товарах або послугах.

Торгівельна модель взаємодії може бути першим початковим етапом. При певних умовах країни переходять до інвестиційної моделі співпраці, продовжуючи розвивати діяльність по формулі Г-Т-Г*. Але тепер кошти можуть вкладаються безпосередньо у виробництво.

Фінансовий сектор економіки, організуючі виробництво в країнах що розвиваються, власно кажучи, купує товар робоча сила, що, як правило, може бути в десятки разів дешевше ніж в розвинутих країнах. Різниця в ціні товару робоча сила в різних системах техно-економічного відтворення стає постійним джерелом прибутку для фінансового сектора, якій отримує мету для свого просування на ринки слаборозвинутих країн.

Проаналізуємо наслідки інвестиційного типу взаємодії двох контурів відтворення з різним рівнем розвитку системи розподілу праці. Як і в першому прикладі, загальні річні витрати праці на виготовлення продукції в кожній країні складають по 1 млрд. л/год. Вартість 1 години праці і співвідношення валют також залишимо на попередньому рівні (1 долар в країні «А» і 1 бат в країні «Б»

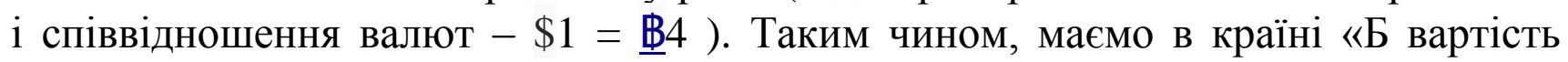
робочої сили в 4 рази дешевшу ніж в країні «А». В подальшому усі показники будемо наводити в доларах, для спрощення розрахунків. Так сукупній валовий продукт, що виробляється в обох країнах, дорівнює \$1,25 млрд. (в країні «А» 1 млрд. дол. і в країні «Б» 0,25 млрд. дол.), сукупний попит також дорівнює $\$ 1,25$ млрд. (в країні «А» 1 млрд. дол. і в країні «Б» 0,25 млрд. дол.). Відповідно, в обох системах відтворення обсяги виробництва і споживання повністю збалансовані.

Таким чином, якщо в країні «Б» вартість робочої сили в чотири рази дешевша ніж в країні «А», то існує джерело отримання прибутку за рахунок різниці в вартості робочої сили. Для цього достатньо частину контуру відтворення з країні «А» перенести на територію країні «Б». В нашому прикладі, припустимо, цей обсяг складає $40 \%$ виробництва - 400 млн. л/год. Маємо контур відтворення країни «А», якій розташувався на материнській території в розмірі - 600 млн. л/год. і в країні «Б» - 400 млн. л/год. В той же час, безпосередньо в контурі відтворення країні «Б» нічого не змінилось. 
Визначимо баланс виробництва і споживання країн, торгівельне сальдо i прибуток. Валовий продукт країні «А», який виробляється в межах її власного контуру відтворення, складає 1 млрд. дол., але при цьому кількість зайнятих у виробництві, що розташовано безпосередньо на їі території, скоротилось до 600 млн. л/год. Загальний рівень доходів ії зайнятого населення, відповідно, складає лише 600 млн. дол. В країні «Б» кількість зайнятих у виробництві зросла до 1,4 млрд. л/год, якщо рівень оплати праці залишається без змін, то доходи працюючих в країні становлять 350 млн. дол. Країна «А», в свою чергу, купує у країні «Б» продукцію на суму 400 млн. дол. і має на цю суму дефіцит торгівельного балансу. В країні «Б» відповідно складається профіцит торгівельного балансу і зростання валютних резервів на 400 млн. дол. В обох країнах в цінах країні «А», виробляється валовий продукт на суму 1,25 млрд. дол., але сукупні доходи в обох країнах складають лише 950 млн. дол. При цьому частина грошей з реального сектора економіки в формі прибутку переходить в фінансовий сектор економіки, в нашому прикладі це - 300 млн. дол.

Таким чином, інвестиційна форма взаємодії країн з різним рівнем розвитку системи розподілу праці призводить до порушення балансу виробництва i споживання, скороченню рівня доходів, а від так і споживання в системі розвинутого контуру відтворення, появи безробіття і кризи перевиробництва. В той же час, в розвинутих країнах виникає дефіцит торгівельного балансу, а в країнах що розвиваються та знаходяться на стадії інвестиційної форми взаємодії 3 розвинутими країнами - профіцит. Досить яскраво цей висновок підтверджує аналіз економічних стосунків США і КНР. Більш того, якщо валюта країни виконує функцію світових грошей, а ії система техно-економічного відтворення належить до панівного в світі контуру відтворення [12, с. 91], то дефіцит іiі торгівельного балансу є одним з важливих каналів насичення світового ринку певною кількістю грошей, необхідних для проведення міжнародних розрахунків, здійснення інвестицій і створення валютних резервів.

Особливо треба відмітити те, що певна кількість грошей в формі прибутку 3 реального сектора економіки постійно перетікає в фінансовий сектор і тому ми маємо можливість спостерігати дефляцію в розвинутих країнах незважаючи на значну грошову емісію. Тобто, в даному випадку кількість грошей в реальному секторі економіки постійно зменшується на суму утвореного прибутку, а в фінансовому секторі, навпаки, на цю суму постійно відбувається приплив грошової маси. В результаті утворюється два самостійних кола обігу грошей один в реальному секторі економіки, де гроші працюють по формулі Т(а)-Г-Т(б) і другій - в фінансовому секторі, де обіг здійснюється по формулі $Г-Т-\Gamma^{*} .3$ 
точки зору функцій які вони виконують, ролі яку відіграють в системі відтворення, а також законів обігу яким підкоряються - це, взагалі, різні гроші, які обертаються по різним законам і виконують різні функції. Так, наприклад, зростання грошової маси в реальному секторі економіки призводить до інфляції та зростанню ціни на гроші. I, навпаки, зростання грошової маси в фінансовому секторі призводить до дефляції та зниженню облікової ставки і, відповідно, ціни на гроші.

Якщо ми погоджуємось 3 тим що в процесі відтворення виробництва складається два взаємозв'язаних, але різних кола обороту грошей, то відразу стає зрозумілим звідки в фінансовому секторі з’являються ці самі - Г*, гроші 3 прибутком. Фінансовий сектор забирає їх саме з реального сектору економіки. В реальному секторі економіки, в наслідок такою взаємодії, грошей постійно стає менше, а фінансовий сектор зростає. В реальному секторі виникає дефляція, в наслідок зменшення грошової маси, яка там обертається, а в фінансовому секторі, так чи інакше, виникають «пузирі»

Такий погляд на роль грошей в системі відтворення виробництва породжує питання про природу грошей та їх походження. На нашу думку, існуюче на сьогодні визначення природи грошей не може вважатися коректним хоча б вже тому, що остання визначається через функції які гроші виконують. С точки зору методології, спочатку необхідно визначити їх економічну природу, а потім вже, виходячи з розуміння природи грошей i ïх походження, визначати їх функції в тому чи іншому секторі економіки.

С точки зору загальновизнаної природи грошей, тобто розуміння їх як товару, нехай i особливого, неможливо пояснити, якім чином, в умовах існування паперового стандарту гроші виконують, наприклад, функцію міри вартості, тобто вимірюють вартість усіх інших товарів які представлені на ринку, в той же час не маючи своєї власної вартості? Чому валюти одних країн можуть бути надійно забезпечені державним боргом цих країн, а валюти інших ні, або чому долар США, певним чином, може контролювати фінансовий сектор економіки, а жодна інша валюта ні? Як вже було підкреслено, на ці та інші питання в межах сучасних уявлень про природу грошей дати відповідь неможливо. В той же час, основою будь-якою макроекономічної політики $\epsilon$ розуміння природи грошей та їх функцій в процесі відтворення виробництва i розвитку системи розподілу праці. Тому, безумовно, економічна природа грошей - це важливе i дуже цікаве питання i воно, в найближчій час, повинно стати окремим предметом глибокого економічного аналізу. 
Продовжуючи наше дослідження слід задати ще одне питання. А що, власно кажучи, буде відбуватися, якщо країна в яку прийшли інвестиції підніме вартість своєї робочої сили до рівня розвинутих країн, зважаючи на те, що накопичених валютних резервів за певний період позитивного сальдо торгівельного і платіжного балансу, для цього вистачить? Чи не вирівняються таким чином обсяги виробництва й споживання, та чи не є це шляхом виходу 3 кризи перевиробництва? Відповідь проста. В такому разі контур відтворення виробництва розвинутих країн буде в цьому місті згорнутий і перенаправлений в іншу країну з більш високим потенціалом отримання прибутку, тобто більш дешевою робочої силою.

На останок треба відмітити, що в теперішній час проблеми порушення балансу між виробництвом і споживанням розвинутих країн, вирішуються за рахунок розвитку системи споживчого кредитування і проведення політики кількісного пом'якшення. Таким чином, фінансовий сектор штучно підтримує обсяг попиту на певному рівні. I це, мабуть, в ситуації яка склалася в світовому господарстві є єдиним можливим шляхом підтримання рівноваги на світовому ринку. Тобто на сьогодні це єдиний варіант вирішення проблем, пов'язаних 3 системною економічною кризою. В свій час ми досить детально особливості і наслідки сучасної світової монетарної політики розібрали в роботі $[12$, с. 91$]$.

Висновки. Проведене дослідження дає можливість зробити висновки про те, що економічні форми взаємодії країн з різним рівнем розвитку системи розподілу праці призводять до результатів, які не завжди є для них бажаними. Але в умовах функціонування законів, які $\epsilon$ результатом дії економічних інтересів основних суб'єктів процесу відтворення виробництва, а від так, безумовно, носять об'єктивний характер, так чи інакше, негативні наслідки існують i не можуть бути подоланні простим вдосконаленням системи менеджменту чи маркетингу. Доведено, що проблема знаходиться значно глибше і полягає в наявності протиріччя між основним мотивом економічної діяльності людей в процесі відтворення виробництва - отриманням прибутку і об'єктивним призначенням цього процесу - задоволенням потреб суспільства в певних товарах і послугах. Бурхливий економічний розвиток людства за останній майже 300-х річний період і $є$, так чи інакше, основним результатом його прояву.

На нашу думку, вирішення цього протиріччя лежить в площині зміни основного мотиву економічної діяльності людей на інший спонукальний мотив. Це може бути, наприклад, творчість або розвиток і вдосконалення своїх власних здібностей і навколишнього середовища, тобто саме те, що $є$ притаманним природі людини від народження. 
Наукова новизна проведеного дослідження полягає в запропонованому методологічному підході до аналізу причин і наслідків існування сучасної моделі економіки пропозиції і перевиробництва на основі дослідження економічної природи i ролі фінансового сектора економіки в процесі відтворення виробництва та визначення основних чинників дефіциту торгівельного балансу розвинутих країн, безробіття, дефляції і економічної кризи.

Практичне значення отриманих результатів полягає у можливості використання запропонованого методологічного підходу до аналізу причин i наслідків існування сучасної моделі економіки пропозиції та перевиробництва у прогнозуванні економічного зростання країн, що відносяться до контурів відтворення з різним рівнем розвитку системи розподілу праці.

Перспективами подальших наукових розробок за даним напрямом $\epsilon$ розробка моделі врівноваження платіжного балансу країни із врахуванням моделі економіки пропозиції та перевиробництва, а також міжнародних фінансових потоків.

\section{Лiтература:}

1. Бойкова М. Корінні причини фінансово-економічних криз капіталізму і правові шляхи їх усунення / М. Бойкова // Віче. Ч. І. - 2012. - №10 [Електронний ресурс]. - Режим доступу: http://www.viche.info/journal/3121/

2. Гнатишин М. Динаміка ліберелізаційних процесів у світовій торгівлі / М. Гнатишин / Схід. 2010. - № 2 (102). - С. 50-54. [Електронний ресурс]. - Режим доступу : http:// www.nbuv.gov.ua

3. Горянська Т. В. Сучасні тенденції розвитку міжнародних торговельно-економічних відносин / Т. В. Горянська // Економічний вісник Донбасу. - 2011. - №1. - С. 51-58.

4. Гэлбрейт Дж. К. Великий крах 1929 года / Дж. К. Гэлбрейт // Пер. с англ. Борич С. Э. Минск : «Попурри», 2009. - 256 с.

5. Іващук I. О. Міжнародна торгівля у вирішенні глобальних проблем економічного розвитку країн / І. О. Іващук // Наукові записки. - Серія: Економіка. - 2011.- Вип. 16. - С. 350-359.

6. Кейнс Дж .М. Общая теория занятости, процента и денег / Дж .М. Кейнс // Пер. проф. Любимова Н. Н. - М. : ГелиосАРВ, 2012. - 352 с.

7. Кравчук Н. Я. Фінансові детермінанти поглиблення асиметрій глобального розвитку / Н. Я. Кравчук // Наукові записки. - Серія: Економіка. - 2010.- Вип. 15. - С. 346-356.

8. Макогон Ю. В. Зовнішньоекономічні зв'язки України і залучення інвестицій / Ю. В. Макогон // Стратегічні пріоритети. - 2008. - №3. - С. 208-218.

9. Маркс К. Капитал. Критика политической экономии / К. Маркс. Т. І, кн. І. Процесс производства капитала. - М. : Политиздат, 1978. - 891 с.

10. Мизес Л. Человеческая деятельность: Трактат по экономической теории / Л. Мизес. - М. : Экономика, $2000 .-878$ с. [Електронний ресурс]. - Режим доступу: http://financepro.ru/economy/7567-ljudvig-fon-mizes.-chelovecheskaja-dejatelnost.html 
11. Милль Дж. С. Основы политической экономии / Дж. С. Милль: Пер. с англ. - М. : Прогресс, 1980. $-496 \mathrm{c}$.

12. Мілай А. О. Особливості та наслідки проведення грошово-кредитної політики ФРС США в умовах світової економічної кризи / А. О. Мілай // Економічний вісник НТУУ «КПІ»: зб. наук. праць. - К.: ВПК «Політехніка» - 2014. - №11. - С. 91 - 96.

13. Рикардо Д. Начало политической єкономии и налогового обложения / Д. Рикардо // Соч. в 3х томах, Т.1. - М.: Госполитиздат, 1955. -385 с.

14. Робинсон Дж. В. Экономическая теория несовершенной конкуренции / Дж. В. Робинсон: Пер. с англ. - М. : Прогресс, 1986. - 471 с.

15. Стиглиц Дж. Крутое пике / Дж. Стиглиц Дж. - М.: Эксмо, 2011. - 510 с.

16. Тивончук О. І. Проблеми економіки та управління / І. О. Тивончук, П. І. Стецюк // Фінансові кризи: аналіз причин та механізмів їх прояву// Вісник Національного університету «Львівська політехніка». - 2011. - № 698 [Електронний ресурс]. - Режим доступу: ena.lp.edu.ua:8080/bitstream/ntb/10914/1/16.pdf

17. Тхор О. С. Теоретичні аспекти моделювання виникнення світових економічних криз / О. С. Tхор, С. О. Тхор, М. С. Кроленко // Вісник Східноукраїнського національного університету імені В.Даля. - 2010. - №11 (153) [Електронний ресурс]. - Режим доступу: http://snu.edu.ua/visniksnu/archive.php

18. Хаєк Ф. Частные деньги / Ф. Хаєк. - М. : Институт национальной модели экономики, 1996. $\begin{array}{llllll}- & 118 & \text { c. } & \text { [Електронний } & \text { ресурс]. }\end{array}$ доступу: tristan.biz.ua/shared/files/file/fridrihhaekchastniedengi.pdf

19. Швайка М. Світова фінансова криза та шляхи їі подолання / М. Швайка, А. Пельо // Віче. 2011. - №6. [Електронний ресурс]. - Режим доступу: http://www.viche.info/journal/2477/

20. Шумпетер Й. А. Капитализм, социализм и демократия / Й. А. Шумпетер : Пер. с англ. - М. : Экономика, 1995. - $540 \mathrm{c}$.

21. Энгдаль У. Ф. Боги денег: Уолл-стрит и смерть Американского века / У. Ф. Энгдаль. - СПб. : Гелион-Плюс, - 2011. - 452 с. 